\title{
INSIGHTS
}

In Public Health Journal

Vol 1 No 1

Perspective

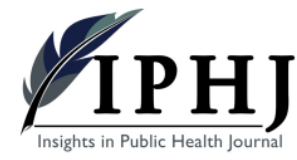

\section{Revisiting the New Indonesia's Marriage Act 2019: will it be effective to prevent adolescent marriage?}

\author{
Dyah Anantalia Widyastari ${ }^{1}$ \\ 1 Institute for Population and Social Research, Mahidol University, Thailand
}

Corresponding author: Dyah Anantalia Widyastari, Salaya, Phuthamonthon, Nakhonprathom 73170, Thailand, Email: dyah.ana@mahidol.ac.th, dyah.anantalia@gmail.com

\begin{abstract}
Indonesia has a long history of adolescent marriage and early childbearing. The religious, sociocultural and economic factors have been pointed out as the major drivers of early marriage while the 1974 Marriage Law was considered 'weak' in preventing the event. As the house of representative has passed the new bill in increasing the minimum legal age of marriage for female from 16 to 19 years old in 2019, a question posed whether the enactment of the new marriage law will be effective in preventing adolescent marriage in Indonesia.
\end{abstract}

Keywords: adolescent marriage, early childbearing, marriage law, Indonesia

The house of representative has just passed the new bill in increasing the minimum legal age of marriage for female from 16 to 19 years old in 2019. After a long debate and a series of failures following disapprovals from conservative and religious affiliations, the government of Indonesia finally is setting up a higher bar for female to start their first union. It will be considered as a success for the feminists since the rising in minimum legal age of marriage at the same age as males implying the excision of gender inequality in marriage. It also brings a new hope for public health practitioners since increasing the age at first marriage is expected 
to lower maternal-related mortality due to adolescent pregnancy. The question is, whether the enactment of the new marriage law will be effective in preventing adolescent marriage? $\mathrm{A}$ closer look to adolescent marriage determinants in Indonesia is required to understand the roots of the problem.

Indonesia has a long history of adolescent marriage and early childbearing. Traditionally, Indonesians married young, and marriage usually took place by parents' initiative ${ }^{1-3}$. While the socioeconomic development of Indonesia has changed the ideas of appropriate age at first marriage of most Indonesians and the proportion of women who married before 17 was declining from 40 percent in 1970s to 11 percent in $1995^{4}$, nevertheless, Indonesia Demographic and Health Survey (IDHS) 2002-2017 reported about 10 percent of Indonesian women have started childbearing before the age of $18^{5-8}$.

It should be acknowledged that the traditional religious view of Indonesians plays a substantial role in driving adolescent marriage in Indonesia. For the conservative Muslim, the desire for marriage is following the Sunnah-which refers to acts that are optional, but meritorious if performed - to prevent 'zina' (unlawful sexual acts) between the unmarried sexually active males and females. Sending a girl to marry early therefore is believed will preserve her 'value' and protect her innocence. On the contrary, postponing ages at first marriage means exposing young women to the risk of 'zina' since the duration of adolescents being in a sexually active state is lengthened ${ }^{9,10}$.

Sociocultural and gendered construction of various community in Indonesia is also supporting adolescent marriage. While Java is believed as the center of development of Indonesia, rural Sundanese in West Java and Madurese of East Java are among those who married the earliest ${ }^{4}$. While early marriage for Madurese is strongly enforced by local custom that considers education for girls are less important than for boys ${ }^{11,12}$, rural Javanese parents of Central Java sent their daughters off for marriage because they were depressed by the norm of having a grown-up unmarried daughter as a shame ${ }^{13}$.

Socioeconomic status of the family was also pointed as a strong predictor of adolescent marriage. All over the world, girls who came from poor family and having a large family size are married and becoming pregnant at an earlier age ${ }^{14-21}$. This finding seems to be universal for developing and less developed countries including Indonesia, where adolescent marriage was seen as an economic relief and schooling was not an option for girls from disadvantaged families.

It is true that more women are now going to school and attained higher education compared to women in the previous decades, and girls who stay at schools are less likely to be pregnant at a younger age ${ }^{17,22}$. It is also true that Indonesia has implemented 6 years compulsory 
education as one of population policy since 1990s, and extended to 9 years with the passing of National Education Law Number 20/2003 $23-26$. Further, 12 years of compulsory education was implemented under the command of President Joko Widodo. It should be noted however, although the government have provided free tuition fees, a considerable portion of Indonesian families could not afford the remaining expenses such as the transportation, books, uniform and other educational-related cost ${ }^{13}$. Program Indonesia Pintar (Smart Indonesia Program) that was established to ensure the access to schooling for all Indonesian aged 6-21 years old has also been challenged by the local government's capability in financing basic education under the decentralization policy ${ }^{27}$.

The new bill of Marriage Act No 16/2019 has only changed the minimum legal age for female, from 16 to 19 as it's stipulated in article 7 paragraph (1). Similar to the amended 1974 act, either parents of the bride or groom could propose a dispensation with sufficient evidence (paragraph 2) and by considering the opinion of the bride and groom candidates (paragraph 3).

It is true that the effects of adolescent marriage have been acknowledged, and the law is expected to prevent low educational attainment and adverse health outcomes for mothers and their children. However, with the ambiguity in its dispensation, there is a doubt that the new law could effectively prevent adolescent marriage, particularly when it's preceded by an unwanted pregnancy. A study found, although at odds with the social norms of Muslim majority, about 7-11 percent of Indonesian women conceived their first child before marriage ${ }^{28}$. In such instance, marriage will be chosen as an option to prevent further family disgrace by making sure the child is born under the wedlock. Regardless of the ages, with sufficient evidence and agreement between parents as it stated in the article 7 paragraph (2) and (3), the court will allow the marriage $e^{29,30}$.

As adolescent marriage is a complex phenomenon that is determined by socioeconomic, religious and cultural aspects, the new law only will not be sufficient as a measure of prevention. Revolution in the attitude toward adolescent marriage is required without threatening the existing sociocultural and religious norms. Efforts to shift the attitude toward adolescent marriage should not be seen as the attempts to weaken sociocultural and religious norms, yet, because it is important for the women and their children's health. Engagement with religious and community leaders should be enhanced, with a focused communication message on the importance of health from religious and sociocultural point of views.

Adolescents should also be informed that early marriage and childbearing might bring them long-term consequences and become disadvantages for their future once they quit schooling. The provision of adequate reproductive health (sexuality) education for young people 
therefore, should be seen as an effort to prevent adolescent pregnancy instead of persuading adolescents to have sex earlier. A bulk of evidence have documented the lacking of reproductive health knowledge and misconceptions toward pregnancy precaution as the major cause of unwanted pregnancy among adolescents ${ }^{31-33}$, whereas sex education showed a positive impact in preventing adolescent pregnancy ${ }^{34-37}$.

Keeping the girls longer at school has been shown as the most effective precaution toward adolescent marriage in many settings. Not only providing the venue for attaining higher education, school also facilitates the diffusion of ideas among young people on the appropriate age for marriage and self-development. School attendance also automatically prevent adolescent marriage because primary and secondary school pupils are restricted to do so. Attaining higher level of education also widen the opportunities for young women to join competitive career and expand the period of mate selection, and thus, delaying the age of marriage ${ }^{38}$. However, considering socioeconomic inequalities of Indonesian families, compulsory education policy should be accompanied by economic supports to increase families' purchasing power in order to extend the opportunities for young women from disadvantaged families to continue schooling and delaying marriage.

\section{References}

1. Malhotra A. Gender and the timing of marriage: Rural-urban differences in Java. Journal of Marriage and Family. 1997;59(2):434-450.

2. Hugo GJ, Hull TH, Hull V, Jones GW. The demographic dimension in Indonesia development. Singapore: Oxford University Press; 1986.

3. Kroef JMvd. Woman and the changing marriage pattern of Indonesia. The American Catholic Sociological Review. 1957;18(2):113-127.

4. Jones GW. Which Indonesian women marry youngest, and why? Journal of Southeast Asian Studies. 2001;32(1):67-78.

5. Statistic Indonesia. Indonesia Demographic and Health Survey 2002. Jakarta: Central Bureau of Statistics; 2004.

6. Statistic Indonesia, Macro ORC. Indonesia Demographic and Health Survey 2007. Jakarta: Central Bureau of Statistic; 2007.

7. Statistic Indonesia, Kemenkes (MoH), NFPCB, ICF. Indonesia Demographic and Health Survey 2012. Jakarta: Central Bureau of Statistic; 2013.

8. National Population and Family Planning Board (BKKBN), Statistics Indonesia (BPS), Ministry of Health (Kemenkes), ICF. Indonesian Demographic and Health Survey 2017. Jakarta, Indonesia: BKKBN, BPS, Kemenkes, and ICF; 2018.

9. Martin-Anatias N. On being a "good" Indonesian Muslim woman: An autoethnography. Humanity \& Society. 2018:0160597618814872.

10. Sarwono SW. Women in Indonesia. Women's Evolving Lives: Springer; 2017:59-72.

11. Herawati N, Rohmah N. Culture Matchmaking in Madurese Ethnic: A Study of the Motives, Factors and Impacts in Marriage Life. International Journal of Psychosocial Rehabilitation. 2020;24(1).

12. Muhith A, Fardiansyah A, Saputra M. Analysis of causes and impacts of early marriage on madurese sumenep East Java Indonesia. Indian Journal of Public Health Research \& Development. 2018;9(8):1495-1499.

13. Widyastari DA, Isarabhakdi $P$, Shaluhiyah Z. Intergenerational Patterns of Early Marriage and Childbearing in Rural Central Java, Indonesia. Journal of Population and Social Studies [JPSS]. 2020;28(3):250-264. 
14. Woodward L, Fergusson DM, Horwood LJ. Risk factors and life processes associated with teenage pregnancy: Results of a prospective study from birth to 20 years. Journal of Marriage and Family. $2001 ; 63(4): 1170-1184$.

15. Olausson PO, Haglund B, Weitoft GR, Cnattingius S. Teenage childbearing and long-term socioeconomic consequences: A case study in Sweden. Family Planning Perspectives. 2001;33(2):70-74.

16. Furstenberg FF, Jr. As the pendulum swings: Teenage childbearing and social concern. Family Relations. 1991;40(2):127-138.

17. Kiernan KE. Becoming a young parent: A longitudinal study of associated factors. The British Journal of Sociology. 1997;48(3):406-428.

18. Lee M-C. Family and adolescent childbearing. Journal of Adolescent Health. 4// 2001;28(4):307312.

19. Williamson NE. Motherhood in childhood: Facing the challenge of adolescent pregnancy: UNFPA state of world population 2013: United Nations Population Fund; 2012.

20. Fergusson DM, Woodward LJ. Teenage pregnancy and female educational underachievement: $A$ prospective study of a New Zealand birth cohort. Journal of Marriage and Family. 2000;62(1):147161.

21. Paik A. Adolescent sexuality and the risk of marital dissolution. Journal of Marriage and Family. 2011;73(2):472-485.

22. Dillon ME, Cherry AL. An international perspective on adolescents pregnancy. In: Cherry AL, Dillon $\mathrm{ME}$, eds. International Handbook of Adolescent Pregnancy. New York: Springer; 2014.

23. Suryadarma D, Jones GW. Education in Indonesia: Institute of Southeast Asian Studies; 2013.

24. Statistic Indonesia. Indonesian Population Census 2010. Jakarta: Statistics Indonesia; 2010.

25. Statistic Indonesia. Secondary Education Statistics. Jakarta: Ministry of Education; 2017.

26. Indonesia PR. Undang-undang Republik Indonesia nomor 20 tahun 2003 tentang Sistem Pendidikan Nasional. Jakarta: The Government of the Republik of Indonesia; 2003.

27. Rosser A, Sulistiyanto P. The Politics of Universal Free Basic Education in Decentralized Indonesia: Insights from Yogyakarta. Pacific Affairs. 2013;86(3):539-560.

28. Widyastari DA, Isarabhakdi $P$, Vapattanawong $P$, Völker $M$. Rethinking early childbearing in Indonesia: is it preceded by a premarital first birth? International journal of adolescent medicine and health. 2019.

29. O'shaughnessy K. Gender, state and social power in contemporary Indonesia: Divorce and marriage law: Routledge; 2009.

30. Katz JS, Katz RS. Legislating social change in a developing country: the new Indonesian marriage law revisited. The American Journal of Comparative Law. 1978;26(2):309-320.

31. Widyastari DA, Shaluhiyah Z, Widjanarko B. Urinating after sexual intercourse prevents pregnancy: adolescents' misconceptions of reproductive health knowledge. Jurnal Kesehatan Reproduksi. 2011;1(2 Apr):102-112.

32. Michie L, Cameron ST, Glasier A, Wellings K, Loudon J. Myths and misconceptions about intrauterine contraception among women seeking termination of pregnancy. J Fam Plann Reprod Health Care. 2014;40(1):36-40.

33. Weed K, Nicholson JS, Farris JR. Teen pregnancy and parenting: Rethinking the myths and misperceptions: Routledge; 2014.

34. Cook SM, Cameron ST. Social issues of teenage pregnancy. Obstetrics, Gynaecology \& Reproductive Medicine. 2015;25(9):243-248.

35. Chin HB, Sipe TA, Elder R, et al. The Effectiveness of Group-Based Comprehensive RiskReduction and Abstinence Education Interventions to Prevent or Reduce the Risk of Adolescent Pregnancy, Human Immunodeficiency Virus, and Sexually Transmitted Infections: Two Systematic Reviews for the Guide to Community Preventive Services. American Journal of Preventive Medicine. 2012/03/01/ 2012;42(3):272-294.

36. Lindberg LD, Maddow-Zimet I, Boonstra H. Changes in adolescents' receipt of sex education, 2006-2013. Journal of Adolescent Health. 2016;58(6):621-627.

37. Lindberg LD, Maddow-Zimet I. Consequences of Sex Education on Teen and Young Adult Sexual Behaviors and Outcomes. Journal of Adolescent Health. 2012/10/01/ 2012;51(4):332-338.

38. Widyastari DA, Isarabhakdi P. Suharto's population policy in contemporary Indonesia: family planning program, marriage act or compulsory education has the greatest impact to fertility decline? Public Health of Indonesia. 2016;2(2):40-46. 